\title{
Halal Certification among SMEs in Kota Kinabalu, Sabah
}

\author{
Haslinda Hasan $^{1 *)}$, Rini Suryati Sulong ${ }^{2}$, Geoffrey Harvey Tanakinjal ${ }^{3}$ \\ ${ }^{1,2,3}$ Universiti Malaysia Sabah, Malaysia \\ *) Corresponding author: haslinda@ums.edu.my
}

\begin{abstract}
Halal is an important concept that enables and simplifies consuming process of food and beverage products especially for Muslim consumers. The study believes that the development of Halal is a communally obligatory (fardhu kifayah) for that SMEs and a personally obligatory (fardhu ain) for the Muslim consumer. The Government of Malaysia has already recognized the importance of SMEs, implemented various policies; action plans, and also introduced Halal related programs to assist the SMEs. The objectives of the study are to identify the awareness and perception towards Halal certification among SMEs in Sabah. 42 SMEs were participated in the study; the results indicated that they are aware of the role of Halal certification, and how Halal will make them competitive in the market. Majority of them are keen to become Halal certified company however the SMEs responded that to be Halal certified company the process is expensive and complicated. This paper is hoped to contribute to better understanding of current situation of how Halal certification can help SMEs to grow their businesses. Further study on this matter is suggested in order to gain more accurate, interesting and detailed information on the issue.
\end{abstract}

Keywords: awareness, halal, halal certification, perception, SME

\begin{abstract}
Abstrak
Halal adalah konsep penting yang memungkinkan dan menyederhanakan proses konsumsi produk makanan dan minuman terutama bagi konsumen Muslim. Peneliti percaya bahwa pengembangan Halal adalah kewajiban bersama (fardhu kifayah) untuk UKM dan kewajiban pribadi (fardhu ain) untuk konsumen Muslim. Pemerintah Malaysia telah mengakui pentingnya UKM, menerapkan berbagai kebijakan, rencana aksi, dan memperkenalkan program terkait halal untuk membantu UKM. Tujuan dari penelitian ini adalah untuk mengidentifikasi kesadaran dan persepsi terhadap sertifikasi halal di antara UKM di Sabah, Malaysia. Sebanyak 42 UKM berpartisipasi dalam penelitian ini. Hasil menunjukkan bahwa mereka sadar akan peran sertifikasi halal, dan bagaimana halal akan membuat mereka kompetitif di pasar. Sebagian besar dari mereka ingin menjadi perusahaan bersertifikat halal, namun UKM menjawab bahwa untuk menjadi perusahaan bersertifikat halal membutuhkan proses yang rumit dan biaya yang mahal. Penelitian ini diharapkan dapat berkontribusi terhadap pemahaman yang lebih baik tentang situasi saat ini tentang bagaimana sertifikasi halal dapat membantu UKM untuk mengembangkan bisnis mereka. Studi lebih lanjut tentang masalah ini disarankan agar dapat diperoleh informasi yang lebih akurat, menarik, dan terperinci tentang masalah ini.
\end{abstract}

Kata kunci: kesadaran, halal, sertifikasi halal, persepsi, UKM 


\section{Introduction}

Halal refers to something that is allowed, no binding prohibition on it, and is required from the perspective of Islamic law. The word 'Halal', literally means permissible and in translation it is usually used as lawful. The opposite of Halal is Haram, which means prohibited or unlawful. For the Muslims, consuming Halal products and services are an order of Allah and as an essential part of the Islamic faith.

Prophet Mohammad (P.B.U.H) said: "Verily, the lawful (Halal) is clear and the unlawful (Haram) is clear, and between the two of them are doubtful matters about which many people do not know. Thus, he who avoids doubtful matters clears himself in regard to his religion and his honour, and he who falls into doubtful matters will fall into the unlawful as the shepherd who pastures near a sanctuary, all but grazing therein. Verily, every king has a sanctum and the sanctum of Allah is his prohibitions. Verily, in the body is a piece of flesh which, if sound, the entire body is sound, and if corrupt, the entire body is corrupt. Truly, it is the heart." [Sahih Bukhari 52, Sahih Muslim 1599]

The previous studies also mentioned that the Halal logo was not only searched and trusted by Muslim consumers but also by the non-Muslim consumers. As indicated by Hornby and Yucel (2009), the non-Muslim European consumers purchased Halal certified products because they believed in the quality and safety of the product. As mentioned by Shafie and Othman (2006), and supported by Zulfakar, Anuar, and Ab Talib (2014), Halal certification cultivates or fosters confidence and belief that the product has gone through the needed Shariah requirements. In Malaysia, the Halal certification of food products was introduced since 1974, by Jabatan Kemajuan Islam Malaysia (JAKIM). Since then, all products and services especially the food and beverage, must get the approval from JAKIM and/or the respective state's religious council that is recognized by JAKIM in order to use the Halal logo (known as Halal Malaysia). For the purpose of Halal certification, JAKIM has to ascertain the Halal status of the product at every stage and at every process involved by carrying out an official site inspection on the plants purposely to examine on how the Halal status of the raw material is maintained and monitored at all times. Halal MS1500:2004 standard was introduced and become a practical guideline for the food manufacturing industry in Malaysia in relation to the preparation and operation of Halal food products, as well as for any trade or business related to use of food products. This guideline is meant to be used together with the MS1480:1999 (Food Safety) and MS1514:2001 (General Principles of Food Cleanliness) (Md. Sawari et al., 2015). According to Blacker \& Bonne (2005), Muslim consumers, in particular, are more confident to purchase products that have the Halal logo rather that those with other quality-based certification such as the ISO labels.

Currently, there are 27 Halal standards across a vast array of sectors in Malaysia:

- Production

- Preparation

- Handling and storage of food; and

- Halal pharmaceuticals and more.

In the Twelfth Malaysia Plan, 2020-2025, Halal industry synergies will have to be moved to the centre stage. As technology will yield more Halal-certified solutions, understanding the needs and emerging attitudes of this fast-growing consumer group will be critical. In addition, the sector holds great potential to accelerate economic impact and expand Malaysian companies' capability. In 2017, Malaysia recorded RM43.3 billion in Halal exports, which made up $4.6 \%$ of the nation's total exports of RM935.4 billion. The 
top importers of Halal products from Malaysia were Singapore (RM4.9 billion), China (RM4.9 billion), Japan (RM2.8 billion), the US (RM2.7 billion) and Indonesia (RM2.2 billion). As shared by Emir Zainul (2019) Malaysia External Trade Development Corp (Matrade) is targeting the export value of Halal products and services to further increase by $5 \%$ in 2019, as it seeks to encourage local Small and Medium Enterprises (SMEs) to use the nation's competitive advantage and tap into the growing industry.

The Small-Medium Enterprises (SMEs) are considered as an important segment that contributes to economic growth and make up the vast majority of businesses in most countries. 98.5\% $(907,065)$ of business establishments in Malaysia are SMEs, in 2016 SME contributes 36.6\% of Malaysia's GDP (SME Annual Report, 2018/2019).

Table 1. Number of SMEs establishments in Malaysia

\begin{tabular}{lcc}
\hline State & Total SMEs & $\%$ \\
\hline Selangor & 179,271 & 19.8 \\
WP Kuala Lumpur & 133,703 & 14.7 \\
Johor & 98,190 & 10.8 \\
Perak & 75,140 & 8.3 \\
Pulau Pinang & 66,921 & 7.4 \\
Sarawak & 61,036 & 6.7 \\
Sabah & 55,702 & 6.2 \\
Kedah & 48,894 & 5.4 \\
Kelantan & 46,618 & 5.1 \\
Pahang & 37,573 & 4.1 \\
Negeri Sembilan & 32,721 & 3.6 \\
Melaka & 31,361 & 3.5 \\
Terengganu & 29,324 & 3.2 \\
Perlis & 6,808 & 0.8 \\
WP Labuan & 2,567 & 0.3 \\
WP Putrajaya & 1,236 & 0.1 \\
\hline Total SMEs & 907,065 & 100.0 \\
\hline Source: Department & &
\end{tabular}

Source: Department of Statistics Malaysia (2016)

Since 1 January 2014, the Malaysian institution known as the Majlis Pembangunan PKS Kebangsaan (SME Corp. Malaysia and Majlis Pembangunan PKS Kebangsaan, 2013) defines SMEs as:

- Manufacturing sector, with annual sales not more that RM50 million or having not more than 200 full time employees at one time

- Service and other sectors, with annual sales not more than RM20 million or having not more than 75 full time employees at one time (SME Corp, 2013)

Depending on the country, governments may use a range of policies to encourage growth of SMEs. The Government of Malaysia has recognized the SMEs as the backbone of the economy, various policies, action plans has implemented to support the SMEs. In addition, few Halal programs also been introduced to assist the SMEs in developing their business (Char et al., 2010). In the April 2013, HDC, Design Development Centre (DDEC), a unit of Majlis Amanah Rakyat (MARA) and SIRIM Bhd. has signed strategic partnership agreements for the provision of services to improve the packaging of Halal products to enhance competitiveness and business performance of local Halal producers especially the SMEs. Nestle Malaysia is also supporting the growth of SMEs in Malaysia by sharing its knowledge and expertise in the local Halal food industry in adding value and raise their standards to enable them to compete in the global market and win consumers' confidence (SME Corporation Malaysia, 2019). 
Hamid et al. (2017) mentioned that the low level of awareness and lack of concern about the implementation of the Halal industry are the two major factors that justify the scenario of many manufacturers, especially Bumiputera who are still reluctant to apply for Halal certification. In 2013, there are 40,884 SMEs in Sabah, however, only 370 are Halal certified SMEs. The percentage of the Halal certified SMEs in Sabah begs the question of why such a small percentage, though the Halal industry has a very promising market potential both locally and globally. Among the reasons is that they have issues in fulfilling the requirement for Halal certification, they also believe that the process is expensive and complicated to become a Halal certified company.

Therefore, the existing SMEs should take the opportunity to be more proactive in regards to the production of Halal products, because its can become a competitive advantage to the SMEs to expand their business locally and globally. Bistari (2004) states the four benefits of Halal logo to the SMEs, firstly, the consumer confidence, secondly competitive advantage, thirdly quality of the products and the last one as a mechanism to audit and monitor Halal food. This argument was supported by Ramli (2015), Halal legislation is needed (1) to protect the consumers, (2) to ensure that the Halal food producers fulfil their moral obligation towards the consumers, and (3) to facilitate halal food trade for both local and global market. Based on the supported views of the mentioned study, the existence and role of the SMEs in Malaysia shall be considered as the backbone of the country prosper economy, that is why the government always take suitable action to support the SMEs.

As mentioned in the previous studies, the Muslim consumers perceived products with the Halal logo have more meaning and more important compared to those which are carrying ISO or similar certification (Fleck, 1997; Blackler \& Bonne, 2005; Bonne \& Verbeke, 2006; Shafie \& Othman, 2006). Moreover clients' expectations of Halal service quality from the respective agency such as JAKIM in Malaysia are higher than what they perceive (Zainalabidin et al., 2012). As stated by Wilson and Liu (2011), the challenges faced by marketers is to identify, understand and respond to the Muslim consumer behaviour and corporate practices points towards perspectives which reframe the Halal. In deeper meaning, the concept of Halal is an example of fardhu kifayah (communally obligatory), and at the same time boosts customer's trust and confidence towards products. According to Ministry of International Trade and Industry (MITI) among the problems that faced by the local manufacturer in Malaysia is they are lacking of competitive edge compared to advanced nations in terms of processing technology, product quality, Research and Development (R\&D), distribution network and also brand building (MITI, 2004). In addition, the process is dynamic and cyclical, due to hypersensitivity, hyper-interactivity and environmental factors that influencing Muslim perceptions of what is Halal.

There is past studies that mentioning the Halal food certification and business issue that support the notion of this study. (Table 2) 
Table 2. Studies on Halal certification

\begin{tabular}{|c|c|c|}
\hline Author (year) & Quotation & Issue \\
\hline $\begin{array}{l}\text { Ab Talib, Chin, and } \\
\text { Fisher (2017) }\end{array}$ & $\begin{array}{l}\text { "[Halal food certificate] as a tool to gain superior } \\
\text { business performance." } \\
\text { "[Halal food certificate] food companies have } \\
\text { the potential to improve the productivity and } \\
\text { standardizing internal operations." }\end{array}$ & $\begin{array}{l}\text { Business performance } \\
\text { Increase productivity } \\
\text { Standardizing products }\end{array}$ \\
\hline $\begin{array}{l}\text { Ab Talib, Abdul } \\
\text { Hamid, and Chin } \\
(2016)\end{array}$ & $\begin{array}{l}\text { "[Halal certification] will affect the growth of } \\
\text { the consumer's base, increase the numbers of } \\
\text { consumers and also increase the revenue of the } \\
\text { firms." }\end{array}$ & $\begin{array}{l}\text { Business expansion } \\
\text { Increase the consumers } \\
\text { Increase revenue }\end{array}$ \\
\hline $\begin{array}{l}\text { Noordin et al. } \\
(2014)\end{array}$ & $\begin{array}{l}\text { "[...] Halal certification is a prerequisite for the } \\
\text { global Halal market }[\ldots] "\end{array}$ & $\begin{array}{l}\text { Global market entry } \\
\text { Assist market expansion }\end{array}$ \\
\hline $\begin{array}{l}\text { Noordin et al. } \\
(2009)\end{array}$ & $\begin{array}{l}\text { "[...] Halal certification and logo are important } \\
\text { elements in gaining market shares and retaining } \\
\text { customers." }\end{array}$ & $\begin{array}{l}\text { Market share expansion } \\
\text { Customer retention }\end{array}$ \\
\hline Abdul et al. (2008) & $\begin{array}{l}\text { "[...] Halal certification is able to promote the } \\
\text { confident, trust and satisfaction of the targeted } \\
\text { consumers." }\end{array}$ & $\begin{array}{l}\text { Enhanced customer } \\
\text { confidence } \\
\text { Consumer satisfaction }\end{array}$ \\
\hline
\end{tabular}

Based on the mentioned studies, the Halal industry can increase the income and quality of people's life through trade, investment, service provision and employment opportunities. A study by Soltanian et al. (2016) indicated that the entrepreneurs or the SMEs, must be exposed to business opportunities and must expand the market for Halal products by sharing knowledge and the success of Halal entrepreneurs in various business fields. The SMEs in Sabah must grab this opportunity to expand their business via entering the Halal market. Halal is a global issue, in Indonesia for example, Halal certification is expected to have a positive effect on SMEs. Many established SMEs such as restaurants have readily accepted and sought their Halal certificates through MUI (Majelis Ulama Indonesia). However, the smaller SMEs like the street food vendors are not ready to comply with the regulation requiring businesses to possess the Halal certificate, because they see that the Halal certificate could create complications for them while not really adding any new value to their businesses (Hasyim, 2019). The scenario is similar with what is happening in Malaysia, Halal certification is easily accepted by the established and medium sized SMEs but not the micro enterprises. For the past years, the trend shows that the Halal logo is seen as an image sought out particularly by Muslim consumers, both locally and globally. Thus, the research objective for the study is to identify either the SMEs in Sabah aware of the importance of Halal certification and to examine what is their perception towards Halal certification. Generally, the study would like to get the answer whether the SMEs in Sabah ready to involve in Halal industry as part of their business expansion and development strategy.

\section{Methods}

\section{Participants}

The study used purposive sampling technique. Majority of the 42 respondents that involved in the study were Microenterprises.

\section{Measures}

The questionnaire was designed in a statement format and then tested for reliability. Part A collate the demographic of the SMEs among the questions are the 
gender of the owner, education level, duration of business establishment and Halal status of the SMEs. For Part B: Awareness towards Halal Certification, there are five questions and also five questions for Part C: Government Support, the respondents need to select their agreeableness level by using 5-point Likert scale, whereby "1" indicate Strongly Disagree and "5" indicates Strongly Agree". For Part D: Perception towards Halal Certification, there are six questions, the respondents need to select their agreeableness level by using 5-point Likert scale, whereby " 1 " indicate Not Important and "5" indicates Strongly Important". Part E: consists of two questions on the knowledge of Halal mobile apps in Malaysia. Table 3 showed the questions for awareness, Halal monitoring and perceptions of Halal.

Table 3. The measurement items

\begin{tabular}{lll}
\hline Variable & Item & Adapted from \\
\hline Awareness & Q5. The SME is aware of the importance of Halal & Abdul (2014) \\
& certificate & \\
& Q6. The SME is aware of the rigorous application & \\
process certification & \\
& Q7. Ownership Halal certificate is increase consumer & \\
confidence towards the SME products & \\
& Q8. Halal Certification will help to develop SME & \\
performance & \\
& Q9. Halal Certification will make SMEs more & \\
& competitive & \\
\hline Halal Monitoring & Q10. Regulatory framework is sufficient & \\
& Q11. Proper monitoring mechanism & \\
& Q12. Government proactive enforcing Halal certification \\
& Q13. Halal transportation system is effective & \\
& Q14. Sufficient facilities for Halal research centers & Abdul (2014) \\
Perception & towards & Q15. Information about Halal is sufficient \\
Q16. Information about Halal is up to date & \\
& Q17. Information about Halal is difficult to access & \\
& Q18. Information about Halal is published regularly & \\
& Q19. Halal hub information is relevant & \\
& Q20. Sufficient websites on Halal products &
\end{tabular}

\section{Data Collection Technique}

The questionnaires were distributed at the three SMEs events (i) SME Mentoring in Tawau, (ii) Karnival 1 Daerah 1 Industri in Sandakan, and (iii) Karnival PKS di Persada Dunia in Kota Kinabalu. All the three events were chosen because Kota Kinabalu, Sandakan and Tawau are the main districts in Sabah.

\section{Analysis}

SPSS Version 20, were used to analyze the data. To identify socio-economic or demographic characteristics of the participated SMEs, the study used the descriptive analysis. The Reliability Analysis procedure was used to calculate a number of commonly used measures of scale reliability and also to provide information about the relationships between individual items in the scale. Reliability Analysis refers to the fact that a scale should consistently reflect the construct it is measuring. Alpha coefficient ranges in value from 0 to 1 and may be used to describe the reliability of factors. As indicated by Nunnaly (1978), 0.7 to be an acceptable reliability coefficient but lower thresholds are sometimes used in the literature. Kaiser-Meyer-Olkin (KMO) Test is a 
measure of how suited your data is for Factor Analysis. KMO test measures sampling adequacy for each variable in the model and for the complete model and measure the proportion of variance among variables that might be common variance. The lower the proportion, the more suited your data is to Factor Analysis (Norusis, 1993) Finally, Crosstab or Cross Tabulation is used to aggregate and jointly display the distribution of two or more variables by tabulating their results one against the other in 2-dimensional grids.

\section{Findings}

Forty-two respondents were participated in this study, 43\% (18) male and 57\% (24) female (Table 2). Respondents are the owner of the company. The education level stated that majority of them completed the tertiary education level (diploma and above) $59.4 \%$ (25) and $40.4 \%$ (17) reached the secondary level. The respondents owned the established company, $42.8 \%$ manage the business more than 2 years and $26.1 \%$ (11) manage to establish the business more than 5 years and $21.4 \%$ (9) more than 10 years. However, only $9.5 \%$ (4) companies are certified Halal, $88 \%$ (37) interested to apply and in process of applying, only $2.5 \%$ (1) not interested to apply. The profile indicated that the respondents are the SMEs that well established with strong academic background, and aware of the contribution of Halal to SMEs development.

Table 3. Profile of respondents

\begin{tabular}{llcc}
\hline SMEs & \multicolumn{1}{c}{ Category } & Frequency & Percentage (\%) \\
\hline Gender (Owner) & Male & 18 & 43.0 \\
& Female & 24 & 57.0 \\
& Secondary School & 17 & 40.4 \\
& Technical & 13 & 30.9 \\
& Certificate/Diploma & 10 & 23.8 \\
& Degree & 2 & 4.7 \\
Duration & Post Graduate & 4 & 9.5 \\
& 0-1 Year & 18 & 42.8 \\
& 2-5 Years & 11 & 26.1 \\
& 5-9 Years & 9 & 21.4 \\
Halal status & $>10$ & 4 & 9.5 \\
& Yes & 37 & 88.0 \\
& No, but interested & 1 & 2.5 \\
\hline
\end{tabular}

The Bartlett's test for sphericity showed that the correlation matrix was at an appropriate level to perform factor analysis of the data for each scale. All scales reaching a significance level of $p<0.000$. The KMO measure provides a value between 0 and 1 . Small values for KMO indicate that a factor analysis of the variables may not be appropriate, since the correlations between variables cannot be explained by other variables (Norusis, 1993). The Kaiser-Meyer-Olkin measure of sampling adequacy for this study gives 0.837 exceeding the recommended value of 0.6 proven that the variables are satisfactory for factor analysis (Table 4). 
Table 4. KMO and Bartlett's test

\begin{tabular}{lll}
\hline KMO and Bartlett's Test & \\
\hline \multicolumn{2}{l}{ Kaiser-Meyer-Olkin Measure of Sampling Adequacy. } & .837 \\
\hline Bartlett's Test of Sphericity & Approx. Chi-Square & 244.511 \\
& df & 55 \\
& Sig. & .000 \\
\hline
\end{tabular}

Referring to Table 5, the results suggested that the awareness among SMEs could be major determinant factor in applying for the Halal certification. There is strong influence in the respondents' decision to be involved in Halal industry. The SMEs also hope that the respective board will update the Halal information from time to time and try to disseminate information of Halal Hub via the Halal websites. For the government involvement, the SMEs demand the government to be more proactive and supportive to the SMEs especially while dealing with the applying and processing of Halal certification. Simple but strict procedure can be introduced to simplify the Halal certification process. The results for perception indicated that most of the SMEs perceive that to be a Halal certified is a strict and difficult process.

Table 5. Reliability analysis

\begin{tabular}{lcc} 
Variable & N of Item & Alpha \\
\hline Awareness & 5 & 0.830 \\
Knowledge \& Government Support & 5 & 0.828 \\
Perception & 6 & 0.816 \\
\hline
\end{tabular}

The result aligned with Hamid et al. (2017) they indicated that the development of the halal industry in Malaysia is the result of the efforts and cooperation of all parties involved, enhancement of mutual understanding and cooperation between agencies that involved in law enforcement based on the provisions of the law under their respective agencies. They also stated that from time to time, there may be challenges and issues of some aspects of halal-related developments, such as the power overlapping and confusion in information.

However the SMEs agreed that the Halal certification and Halal logo will become a competitive advantage to the company. In addition becoming a Halal certified company will also increase the consumer confidence towards SMEs products, and at the same time will enhance their market share. The finding was supported by Ab Talib et al. (2017), they proved that business performance can be achieved through Halal food certificate implementation, however the the performance would not materialize if the certificate only for display because this could lead to the integrity of Halal food products. Therefore, as suggested by Ab Wahab and Kamarubahrin (2019) the overall marketing efforts should not solely focus on product packaging such as Halal logos and certifications, but also on the quality of the product itself.

This study also tries to get the general feedback about Halal Mobile Apps (HMA) majority of the respondents $76.2 \%$ (32) aware of the HMA and they also interested to register their business in the apps (Table 6). Based on the results, the study believes that in future HMA will be widely use and be part of the promotional tool. At the moment HMA was used to locate Halal food premises and restaurants certified by JAKIM within $20 \mathrm{~km}$ radius from the current location. HDC is actively promoting the mobile apps where 
users will be able to easily obtain mobile access on the Halal directory and Halal industry news and knowledge via the Halal Mobile Apps.

Table 6. Halal mobile apps

\begin{tabular}{llcc}
\hline Information & Category & Frequency & Percentage \\
\hline \multirow{2}{*}{ Aware on Halal Apps. } & Yes & 32 & 76.2 \\
& No & 10 & 23.8 \\
\cline { 2 - 4 } Interested to register & Yes & 42 & 100.0 \\
& No & 0 & 0 \\
\hline
\end{tabular}

\section{Discussion}

The result from this study revealed that the SMEs in Sabah are aware with the significance of the Halal certification and Halal logo for their products. They also agreed that by obtaining Halal Certification will give very lucrative revenue, due to the size of the Halal industry and the industry is growing bigger by time. This is why the government initiate few plans in helping the SMEs to focus on capacity building, financial assistance, market development, facilitation of export, brand development, skill and entrepreneurial training as well as providing necessary infrastructure, institutional and regulatory support for the SMEs to be proactive and more aggressive in developing and expanding their business especially in the Halal industry. However, a strict and complicated application process becomes a barrier to apply for Halal certification. At the present market, the nonMuslim industry players seem ready and aware of the tremendous development of Halal market compared to the Muslims, and they are competing in the Halal market domestically and globally. According to the Halal Industry Development Corporation (2014), there are 34\% Halal Certified companies owned by Bumiputera, whereas $66 \%$ of the companies are the Non-Bumiputeras.

The present Halal market is non-exclusive to Muslims, and has gained increasing acceptance among non-Muslim industry players who associate Halal with ethical consumerism. As supported by Zohar and Marshall (2004), Halal products are the object of business that does not simply relate to gain profit as much as possible, but also relate to the four bases; ethic, morality, social and other sacred values. Based on the previous data, all the SMEs in Sabah either Muslim or non-Muslim owned should ready to be a Halal certified SMEs, because it is a contributing factor in consumer decision and the failure to be Halal certified would be a competitive disadvantage for the SMEs at the current and future market. (Nooh et al., 2016).

Based on the study and supported by previous studies in Malaysia, the Halal certification and Halal logo are part of a government effort to help the consumers especially Muslim consumers to identify the products they use or consume are Halal. For example, Mohani, Hashanah, and Mazlina (2013) stressed that living in a multicultural society as in Malaysia with different religious background, the Muslim consumers' needs assurance that food to be selected and consumed are Halal or fit for consumption because food was prepared by third party. For the industry players, they agreed that by having the products Halal certified could boost their market share and market competitiveness.

At the meantime, various collaboration with relevant Ministries and Agencies namely Jabatan Kemajuan Islam Malaysia (JAKIM), Standards Malaysia, SME Corp. Malaysia and Malaysian Investment Development Authority (MIDA) have helped push the Malaysian Halal Standard to be recognised and accepted at the global stage. In fact, through the initiative by the Ministry of International Trade and Industry (MITI), 
Malaysian Halal Standard is actively promoted to be used as a benchmark for the International Halal Standard. The study believes that the industry players (SMEs) and consumers need to actively play their roles in the well-being of humanity and not just for the sake of making huge profit. Both parties must play their respective roles in making sure that only genuine Halal products exist in the market or else will bring harm and disaster to human life and other creatures on this earth.

As mentioned in Al Quran (Al Qasas 28:77): "But seek, through that which Allah has given you, the home of the Hereafter; and [yet], do not forget your share of the world. And do good as Allah has done good to you. And desire not corruption in the land. Indeed, Allah does not like corrupters."

Noor Azlin \& Hassan (2016) highlighted three fundamental issues related to Halal in Malaysia, firstly the attitude of Muslim consumers towards the products that they consume, the role of industry players in producing the Halal products and finally the enforcement actions to curb fraudulent Halal certificates and Halal logos by the respective agencies. The three elements must be harmonized to ensure that there is no deviation especially from the industry players, which leads to profitability. Halal is not only a concept but it is actually creating a supporting system. The consumers must be selective in making sure that they only consume genuine Halal products, the process is considered as a fardhu ain (personally obligatory). As for the industry players, they must find a way to produce genuine Halal products, genuine in terms of strictly followed, fulfilled the standards and guidelines for Halal certification. This is the example of fardhu kifayah (communally obligatory). The Prophet (saw) already mentioned both obligatory duties: "Seeking knowledge is an obligation upon every Muslim" [Ibn Maajah (AlAlbaani: Saheeh)]

And as written in Al Quran, Surah Al-Anbiya [21:7]: "And We sent not before you, [O Muhammad], except men to whom We revealed [the message], so ask the people of the message if you do not know."

Clearly stated that Muslim consumers must consume Halal products and the SMEs especially that owned by the Muslim must find a way on how to produce Halal products to cater the Muslim consumers. In general, once consumers aware on Halal products means it is a great power to educate manufacturer to acquiring Halal certification. In order to complete the Halal system JAKIM and the State Islamic Councils must actively play their role in monitoring the Halal certification and be proactive in dealing with the Halal issues in order to gain the trust of the Muslim consumers towards the Halal Malaysia certification. In ensuring the Halal system is complete all the existing parties must play their role and keep monitoring and auditing each other. As highlighted by Azmi et al. (2018) and also mentioned by Zailani et al. (2015) Halal integrity is the most influential factors in determining the adoption of Halal. It is hoped that the results from the paper would provide another avenue for government and policy makers to improve their policy decisions and mechanisms of making SMEs in Malaysia to be Halal certified and more responsible in producing Halal products and services. 


\section{Conclusion and Recommendation}

There are shortcomings, conditions or influences that cannot be controlled by the researcher that place restrictions on the methodology and conclusions. Among the limitations are, the number of the respondents, by increasing the number of SMEs probably will enhance the generalizability of the findings. The SMEs also exhibited a certain level of propensity for Halal entrepreneurship. This observation indicated that they were enthusiastic or positive about becoming Halal SMEs. The study tested and verified the hypotheses using a questionnaire survey but was only a cross-section study in nature. This approach limits the ability to imply causality in the relationships among variables. Thus, the survey results were affected by the fact that this study was not able to observe the dynamic changes of attitude, subjective norms and perceived behavioral control in the development process of Halal industry specifically in Sabah and generally in Malaysia. A longitudinal study that examines the relationships over an extended period should be conducted to provide precise results.

Future studies could explore the effect of extrinsic motivations and pro-social motivations. Business practice guided by the spiritual vision is considered capable of leading to achieve specific meaning, objective and value. Zohar and Marshall (2004) mentioned that organization that carrying out business from the in-depth awareness of meaning, rich vision, high responsibility and a series of shared fundamental value will enjoy long term competitive advantage compared to those focusing on their own interest only. As stated by Omar, Muhammad and Omar (2008), Halal was the next benchmark for quality and as supported by Fard and Amiri (2018) the Halal food that produced by the SMEs should be innovative, proactive, opportunist, risk-taker, and customer-oriented in order to achieve better market and innovative performances.

The values of a Halal certificate in a business have broader appeal beyond religion and also contribute to Malaysia's position as a Halal tourism destination and a hub for the global Halal market as targeted by the government. The Halal industry is growing continuously, there are demand and interest from locals and overseas for Halal products and services that are increasing day by day. When such a big opportunity like this emerges, there is a lot of competition, whether SMEs like it or not, they have to invest in certain aspects, such as in technology or obtaining more information, so that they can compete better locally and globally. The adoption of electronic commerce also may be another option to consider for widen the accessibility of the products to consumers (Sultan \& Noor, 2017). It is interesting to note that technology and Halal can be used for Muslims to lead a virtuous life. There is massive potential ahead for other technology uses in Halal and it is limited only by our imagination. In conclusion, the findings and discussion of this study is subjected to certain limitations. Nevertheless, the present study provides a solid platform for future scholars to work on.

\section{References}

Ab Talib, M. S., Abdul Hamid, A. B., \& Chin, T. A. (2016) Can halal certification influence logistics performance? Journal of Islamic Marketing, 7(4), 461-475.

Ab Talib, M. S., Chin, T. A., \& Fischer, J. (2017). Linking halal food certification and business performance. British Food Journal, 119(7), 1606-1618. https://doi.org/10.1108/BFJ-01-2017-0019 
Ab. Wahab, N., \& Kamarubahrin, A. F. (2019) Halal Industry: Are The Business Fully Awake? Journal of Fatwa Management and Research, 16(1), 22-35.

Abdul, M. (2014) Perceptions on Halal Food Certification in Hat Yai, Thailand, International Journal of Economics and Management, 8(1), 178-194.

Al Quran

Azmi, F. R., Abdullah, A., Bakri, M. H., \& Musa, H. (2018). Perception of small medium and enterprises towards halal food supply chain in Malaysia. International Journal of Mechanical Engineering and Technology, 9(11) 821-828.

Bistari, Z. M. (2004). Standardization for halal food. Standards \& Quality News, 11(4). Retrieved from https://www.yumpu.com/en/document/view/38668555/standardisation-for-halalfood

Bonne, K., \& Verbeke, W. (2006). Muslim consumer's motivations towards meat consumption in Belgium: Qualitative exploratory insights from means-end chain analysis. Anthropology of Food, 5. https://doi.org/10.4000/aof.90

Bonne, K., Vermeir, I., Bergeaud-Blackler, F., \& Verbeke, W. (2007). Determinants of Halal meat consumption in France. British Food Journal, 109(5), 367-386

Char, A. K., Yasoa, M. R. B., Hassan, Z., \& Muhammad, M. Z. (2010). Small and medium enterprises (SMEs) competing in the global business environment: a case of Malaysia. International Business Research, 3(1), 66-75. https://doi.org/10.5539/ibr.v3n1p66

Department of Statistics Malaysia. (2016). Small and Medium Enterprises 2015. Retrieved from https://www.dosm.gov.my/

Emir, Z. (2019, January 28). Matrade targets 5\% growth in halal exports for 2019. Retrieved from https://www.theedgemarkets.com/article/matrade-targets-5growth-halal-exports-2019

Fard, M. H. \& Amiri, N. S. (2018). The effect of entrepreneurial marketing on halal food SMEs performance. Journal of Islamic Marketing, 9(3), 598-620

Fleck, L. (1997). Malaysia's diverse cultures offer challengers to importers. Retrieved from http://findarticles.com/p/articles/mi_m3723/is_n5-6_v9/

Halal Industry Development Corporation (2014). Retrieved from http://www.hdcglobal.com/

Hamid, N. A. A. A., Shahwahid, F. M., Othman, N., \& Saidpudin, W. (2017). Challenges and ways improving Malaysia Halal Food Industry. Science International, 29(2), 149.

Hasyim, S. (2019). Becoming a global halal hub: Is Indonesia ready? RSIS Commentary. No 098-15 May 2019

Hornby, C., \& Yucel, S. (2009, November 18). Halal food going mainstream in EuropeNestle. Retrieved from https://www.reuters.com/article/idINIndia44025720091117

Md. Sawari, S. S., Ghazali, M. A., Abu Bakar Yap, S. M., \& Latif, A. A. (2015). E-halal as method and apparatus for halal product detection in Malaysia. Mediterranean Journal of Social Sciences, 6(5), 638-642. https://doi.org/10.5901/mjss 2015.v6n5s2p638

Mohani, A., Hashanah, I., \& Mazlina, M. (2013). Halal food certification: Case of Malaysian SME entrepreneurs. China-USA Business Review, 12(2), 163 -172. https://doi.org/10.17265/1537-1514/2013.02.007 
Nooh, M. N., Nawai, N., Mohd Dali, N. R. S., \& Mohammad, H. (2016). Halal certification: What SME producers should know. Retrieved from https:www.researchgate.net/publication/237318846

Noor Azlin, I., \& Hassan, N. (2016). Mengapa Makanan Halal. Kuala Lumpur: AlMadinah.

Norusis, M. P. (1993). SPSS for Windows. Base System. Chicago: SPSS Inc.

Nunnaly, J. (1978). Psychometric theory. New York: McGraw-Hill.

Omar, W. M. W., Muhammad, M. Z., \& Omar, A. C. (2008, December). An analysis of the Muslim consumers' attitude towards halal food products in Kelantan. Paper presented at the ECER Regional Conference.

Ramli, N. (2015). Laws and regulations on Halal Production. Global Islamic Economy Gateway Retrieved from http://irep.iium.edu.my/50287

Shafie, S., \& Othman, M. N. (2006). Halal certification: An International Marketing Issues and Challenges. In M. K. Welge (Ed.), Proceedings of the IFSAM/VHB VIIIth World Congress 2006: Enhancing Managerial Responsiveness to Global Challenges. Berlin Germany: The International Federation of Scholarly Associations of Management.

SME Annual Report 2018/2019. Retrieved from http://www.smecorp.gov.my/index.php/en/resources/2015-12-21-11-07-06/smeannual-report

SME Corporation Malaysia and Sekretariat bagi Majlis Pembangunan PKS Kebangsaan. (2013). Garis panduan bagi definisi baharu PKS. Retrieved from http://www.smecorp.gov.my/images/pdf/GarisPanduan_Definisi_Baharu_PKS_ updated.pdf

Soltanian, M., Zailani, S., Iranmanesh, M., \& Aziz, A. A. (2016). Motivations of SME entrepreneurs to become halalpreneurs. Journal of Science and Technology Policy Management, 7(2), 173-189. https://doi.org/10.1108/JSTPM-07-2015-0023

Sultan, A. A., \& Noor, S. M. (2017). Absorptive capacity, civil conflict and e-commerce adoption among Iraqi firms. Advanced Science Letters, 23(8), 7992-7995.

The International Trade and Industry Ministry. (2004). Retrieved from https://www.miti.gov.my/

Wilson, J. A. J., \& Liu, J. (2011). The challenges of Islamic branding: navigating emotions and halal, Journal of Islamic Marketing, 2(1), 28-42. https://doi.org/10.1108/17590831111115222

Zailani, S., Kanapathy, K., Iranmesh, M., \& Tieman, M. (2015). Drivers of Halal orientation strategy among Halal food firms. British Food Journal, 117(8), 148163.

Zainalabidin, M., Juwaidah, S., Golnaz, R., Amin Mahir, A., Ismail, A. L., \& Mohd Ghazali, M. (2012). Clients' perception towards JAKIM service quality in Halal certification. Journal of Islamic Marketing, 3(1), 59-71.

Zohar, D., \& Marshall, I. (2004). Spiritual Capital: Wealth We Can Live by Using Our Rational, Emotional and Spiritual Intelligence to Transform Ourselves and Corporate Culture. London: Blumsbury

Zulfakar, M. H., Anuar, M. M., \& Ab Talib, M. S. (2014). Conceptual framework on halal food supply chain integrity enhancement. Procedia - Social and Behavioral Sciences, 121, 58-67. https://doi.org/10.1016/j.sbspro.2014.01.1108 